\begin{tabular}{|l|l|}
\hline Journal Code: RAJU & Proofreader: Mony \\
\hline Article No: RAJU12054 & Delivery date: 20 Oct 2014 \\
\hline Page Extent: 16 & \\
\hline
\end{tabular}

Ratio Juris. Vol. 27 No. 4 December 2014 (461-77)

\title{
Alf Ross on the Concept of a Legal Right
}

\section{TORBEN SPAAK*}

Abstract. In this article, I discuss Alf Ross's claim that the concept of a legal right is best understood as a technical tool of presentation, which ties together a disjunction of operative facts and a conjunction of legal consequences, and that rights statements render the content of a number of legal norms in a convenient manner. I argue that while Ross's analysis is appealing, it is problematic in at least three respects. I also argue, however, that despite these difficulties Ross's analysis deserves our continued attention, because the fundamental idea-that the concept of a legal right must be understood functionally—is sound.

\section{Introduction}

In this article, I discuss Alf Ross's claim that the concept of a legal right is best understood as a technical tool of presentation, which ties together a disjunction of operative facts and a conjunction of legal consequences, and that rights statements render the content of a number of legal norms in a convenient manner. I argue that while Ross's analysis is appealing, it is problematic in at least three respects. First, it is designed primarily to account for one type of legal right concept only, namely, the concept of ownership; and although it can be used to account for other types of legal right concept as well, the practical benefits of doing so will not be anywhere near as impressive as they are in the case of the concept of ownership. Second, Ross's attempt to distinguish the concept of a legal right from other concepts that might also be conceived of as connective concepts-by rather loosely characterizing the situations in which we typically say that a person has a legal right-is not satisfactory, and needs to be supplemented with a characterization along the lines of the choice (or interest) theory of rights. Third, Ross's analysis cannot account for the concept of a legal right as it occurs in the legal object

* Professor of Jurisprudence, Department of Law, Stockholm University. I would like to thank Lennart Åqvist for helpful comments on the article. I would also like to thank Uta Bindreiter and Mauro Zamboni as well as the participants in the advanced seminars in jurisprudence and practical philosophy for helpful comments on an earlier version of the article. Last but not least, I would like to thank Robert Carroll for checking my English. The usual caveat applies, however: The author alone is responsible for any remaining mistakes and imperfections. 
language, as distinguished from the legal meta-language, and this means that its area of application is more restricted than one might believe at first. I also argue, however, that despite these difficulties Ross's analysis deserves our continued attention, because the fundamental idea-that the term "legal right" does not refer, and that therefore the concept of a legal right must be understood functionally-is sound.

I begin by presenting Ross's analysis of the concept of a legal right, the Scandinavian rights debate in which Ross took part, and, briefly, two important themes in Axel Hägerström's philosophy, which inspired Ross and the other participants in the Scandinavian rights debate (Sections 2-4). I then turn to consider more closely, first, the idea of a connective concept and the advantages of Ross's analysis (Section 5), then the three problems mentioned in the previous paragraph as well as a fourth difficulty, viz. a problem of circularity (Sections 6-9), and, finally, two alternative ways of dealing with the fourth difficulty (Sections 10-11). Concluding remarks are found in Section 12.

\section{Ross's Analysis}

Ross's starting-point is that the term "legal right" does not refer-it lacks, as Ross puts it, semantic reference-and must therefore function in some other way (Ross 1957, 820; 1959, 172). Against this background, Ross claims $(1959,174)$ that the concept of a legal right is a technical tool of presentation, or, as I shall say, a connective concept, which ties together a disjunction of operative facts and a conjunction of legal consequences in the following way ( $F$ stands for operative facts, $O$ stands for ownership, and $C$ stands for legal consequences): ${ }^{1}$

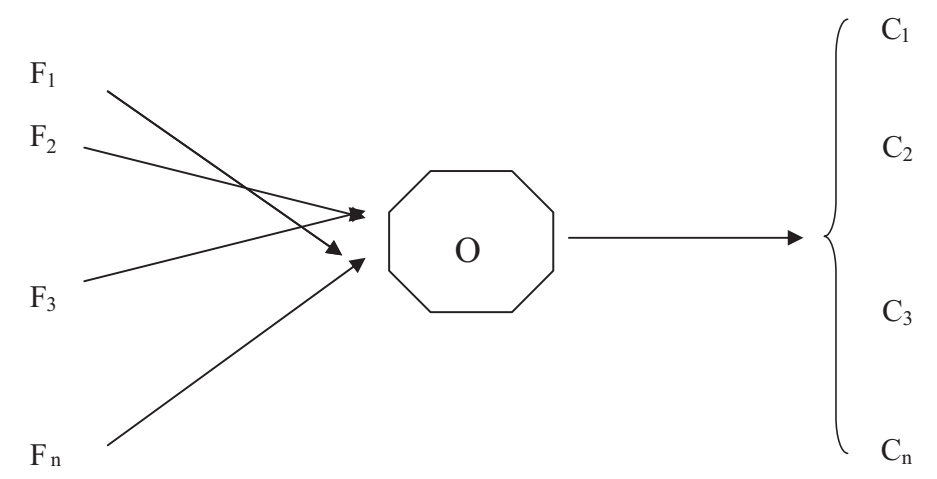

Following Karl Olivecrona (1962, 190), we might say that the concept of a legal right thus conceived fulfils the same function as a junction: A large number of lines (the operative facts) converge into the junction (the legal right), from which a large

${ }^{1}$ Ross does not discuss the precise nature of the connection between operative facts, the concept of a legal right, and the legal consequences, in his analysis. However, Lindahl (2004, 184) seems to contemplate two possibilities in this regard. One may view it either as a matter of logical implication, or as a matter of inference rules. I would prefer the latter alternative. 
number of lines branch out (the legal consequences). On this analysis, to assert that a person has a legal right is to render the content of a number of legal norms in a convenient manner. What we have here, Ross $(1959,172)$ explains, is "a simple example of reduction by reason to systematic order."

The analysis is clearly inspired by Ross's naturalism. That the analysis depends on semantic naturalism in the sense that concepts must be analyzable in empirical terms, if it is to be philosophically adequate, is clear from Ross's rejection of the concept of a legal right as traditionally understood, on the ground that the term "legal right" does not then refer to anything real. ${ }^{2}$ Since he believes that the concept as traditionally understood is unacceptable, Ross proposes that we reconceive it as a connective concept along the lines indicated above. Thus reconceived the concept has been analyzed in empirical terms, viz. in terms of the content of positive, that is, existing legal norms. As Ross () puts it, "the assertion that $A$ possesses the ownership of a thing, when taken in its entirety, has semantic reference to the complex situation that there exists one of those facts which are said to establish ownership, and that $A$ can obtain recovery, claim damages, etc."(Ross 1957, 822; emphasis added). Alternatively, one might say that the content of positive legal norms can be said to be an empirical matter, if and insofar as the determination of the content of such norms is essentially an empirical matter. ${ }^{3}$

Ross's commitment to ontological naturalism is clear from his discussion of the core ideas of Scandinavian realism. Here he explains that whereas jurisprudential idealism is the view that there are two distinct worlds with two corresponding modes of cognition, viz. (i) the world of time and space, which comprises the usual physical and psychological entities that we apprehend with the help of our senses, and (ii) the world of ideas or validity, which comprises "various sets of absolutely valid normative ideas" and is apprehended by our reason (Ross 1959, 65); jurisprudential realism is concerned with the world of time and space, and aims to understand the cognition of law along the lines of modern empiricist science. As he puts it, "[t]here is only one world and one cognition. All science is ultimately concerned with the same body of facts, and all scientific statements about realitythat is, those which are not purely logical-mathematical-are subject to experimental test" (ibid., 67).

Ross points out that his understanding of the concept of a legal right differs markedly from the commonsense understanding of that concept. For, he points out, lawyers as well as laymen often speak of legal rights as if they were some type of entity that follows from certain operative facts and then yields certain legal consequences (ibid., 179). The problem with such a metaphysical conception of legal rights, he explains (ibid.), is that it mistakenly assumes (a) that a legal right is "a single and undivided entity that must exist in a specific subject; and (b) that this subject must be a human being or an organization of human beings." Ross's view is that both assumptions are likely to lead to error (ibid., 179-83). In regard to the first assumption, it is often the case that the various functions (or aspects) of a legal right-such as the power to take legal action, or the power to transfer the

\footnotetext{
${ }^{2}$ In speaking of semantic naturalism, I follow Leiter $(2002,3)$.

${ }^{3}$ Of course, the extent to which this is so is a controversial question, which divides so-called exclusive and inclusive legal positivists. On this, see Coleman (2001, 103-19); Raz (1985); Waluchow (1994).
} 
right-are to be found in different persons. With regard to the second assumption, there is no reason why an animal, say, cannot benefit from somebody's legal duty.

Ross is well aware that his analysis fits other legal concepts as well, concepts such as judge, marriage, and territory, and he therefore proceeds to say something about the circumstances in which we can properly maintain that a person has a legal right (ibid., 175). However, he points out that doing this does not involve "deciding when a right 'actually exists'." For, as he keeps reminding us, the term "legal right" does not refer to "any phenomenon that exists under certain specific conditions" (ibid.). At any rate, he argues that typically the right-holder (i) is on the advantageous side of a legal relation, (ii) has the legal right as a result of a legal regulation, and (iii) is the person who can enforce the right by taking legal action. In addition, he explains, it is usually the case that the right-holder (iv) has the legal power to transfer the right to another person. The concept of a legal right, he concludes, "is typically used to indicate a situation in which the legal order has desired to assure to a person liberty and power to behave-within a specified sphere-as he chooses with a view to protecting his own interests" (ibid., 177). He adds that this means that we do not speak of legal rights in a situation where a person has certain liberties and powers that are intended "for the protection of social interests" (ibid.). In such a case, he explains, we speak instead of a person's authority or power. The concept of a legal right, in other words, "indicates the autonomous self-assertion of the individual" (ibid.).

Ross's attempt to distinguish the concept of a legal right from other concepts that might also be conceived of as connective concept is of particular interest in this context, because it does not indicate what is necessarily the case, but only what happens to be the case, and because the absence of conceptual necessity appears to be a result of Ross's naturalist approach to conceptual analysis. ${ }^{4}$

\section{The Scandinavian Rights Debate ${ }^{5}$}

Ross's analysis of the concept of a legal right was a result of the so-called Scandinavian rights debate in the 1940s and 1950s, in which Ross took part. The debate began in 1945 with Per Olof Ekelöf's analysis of legal inferences. Among other things, he was trying to find an expression that could be substituted for terms such as "right" or "claim" in legal inferences without undermining the legal function of such inferences (Ekelöf 1945, 243). The following is an example of the types of legal inference that he analyzed:

(P1) If a loan is granted, a claim comes into existence.

(P2) A loan is granted.

(C) A claim comes into existence.

$\left(\mathrm{P} 1^{*}\right)$ If a claim exists, payment must be made on the day it is due.

$\left(\mathrm{P} 2^{*}\right)$ A claim exists.

$\left(C^{*}\right)$ Payment must be made on the day it is due.

\footnotetext{
${ }^{4}$ For more on this general theme, see Bealer (1987).

${ }^{5}$ For an account of this debate, see Sundby (1968).
} 
Ekelöf maintained that terms such as "claim" or "right," when used in legal inferences, do not refer to one thing and one thing only, but to different things in different contexts. Specifically, he argued that they refer to a complex of legal consequences in the first type of inference above and to (what he referred to as) a complex operative fact, that is, a disjunction of operative facts, in the second type (ibid., 247-8).

He concluded that it is characteristic of legal inferences in which these terms occur that the relevant fact(s) is (are) subsumed "under a whole complex of legal rules that are summarized in one single legal rule, whose antecedent indicates a complex operative fact and whose consequent is a complex of legal consequences" (ibid., 253; my translation).

But Ivar Strahl $(1946 / 47,489)$ rejected Ekelöf's claim that "claim" and "right" refer to different things in different contexts-if they did, he reasoned, inferences such as the ones considered by Ekelöf could not be valid, since they would then involve the fallacy known as quaternio terminorum. ${ }^{6}$ Strahl therefore suggested that we take these terms to refer to a complex of operative facts and nothing else (ibid., 490-7). Nevertheless, he agreed with Ekelöf that the concept of a legal right does function as a kind of tool of presentation in legal thinking (ibid., 484-5).

Some years later, the philosopher Anders Wedberg defended an analysis of the concept of ownership along the lines of the analyses proposed by Ekelöf and Strahl. ${ }^{7}$ Wedberg argued that the main function of the concept of ownership is to make legal inferences possible:

The concept of property or ownership is, in a certain sense, merely auxiliary. To establish that such and such an object $O$ is the property of a person $P$ at a time $t$, seems to be of interest only as a step toward concluding that, hence, such and such legal consequences ensue. By employing the general sentences (8)-(15) [If $A_{i}$; then $O$ becomes the property of $P$ at $t$; If $C_{i}$; then $O$ ceases to be the property of $P$ at $t$. Etc.] as our premises, we can, in a greater or lesser number of steps, derive from a given condition which does not involve the concept of property a certain consequence which likewise does not involve that concept. To make possible such logical transitions appears to be the essential function of the statement form (7) [ $O$ is the property of $P$ at $t$.] and of those sentences in which it occurs. (Wedberg 1951, 272)

We see, then, that a number of Scandinavian legal scholars embraced the idea that the concept of ownership functions in legal thinking as a connective concept. The appreciation of this type of analysis among the Scandinavians can, I believe, be traced back to Östen Undén's distinction between concepts of substance, which correspond to things that exist in reality as ideas about these, and concepts of function, which have reference to relations or fictitious phenomena. As Undén explained: a

[c]riticism of the concept of a right is fully justified if it is directed against the view of the same as a concept of substance. But if it is understood as a concept of function with the task of facilitating the clarification of the content of the legal rule system, then of course the

\footnotetext{
${ }^{6}$ As Lennart Åqvist has pointed out to me, one might perhaps be able to avoid this problem by taking into account the fact that the inferences in question involve hidden references to different points in time.

7 Lindahl $(2004,189)$ points out that Wedberg was actually the first person to propose an analysis along the lines discussed here, viz. in a lecture in Uppsala in 1944.
} 
concept cannot be criticized with the objection that no 'rights' exist. For the concept does not refer to any real forces that are assumed to exist in natural reality or in a supernatural sphere, but it is a constructed concept intended to indicate a certain state of affairs. It is a concept of function that aims to make clear for thought the theoretical content of the legal rule system or the practical application thereof in a concrete case. The concept should not be examined in respect to its truth value, since it never presumes to reflect a natural context, but in respect to its practicality. (Undén 1928, 173) ${ }^{8}$

Undén's analysis was a reaction against what Undén considered to be exaggerated claims by some followers of Axel Hägerström. Vilhelm Lundstedt (1928, 84), for example, had said that "as a matter of fact, there are no rights, and the concept of a right is a logical impossibility that legal science could only work with up until our time owing to certain fundamental mistakes. ${ }^{\prime \prime}$ But in spite of such exaggerated claims by Lundstedt and others, Hägerström was an important source of inspiration for a whole generation of Scandinavian legal thinkers, including Ross. ${ }^{10}$ Let us therefore take a brief look at Hägerström's philosophy.

\section{Axel Hägerström: Naturalism and Non-Cognitivism ${ }^{11}$}

Hägerström's legal philosophy is erected on a foundation consisting of naturalism and non-cognitivism. As I intimated above, ontological naturalism is the idea that there is one (and only one) all-encompassing spatio-temporal framework, and that everything that exists is to be found in this framework. As Hägerström puts it in a review of Hans Kelsen's Hauptprobleme der Staatsrechtslehre:

A legal prescript is, in fact, for him [Kelsen] a judgment concerning a supernatural existent, which nevertheless (at least in so far as his view is carried out consistently) must be completely realized in the world of nature. But this is an absurd idea. The supernatural juridical system cannot be thought of as even existing alongside the natural order. For no knowledge of any reality is possible except through relating its object to a systematically interconnected whole. But the supernatural and the natural systems, as being different in kind, cannot be co-ordinated in a single system. Therefore, so far as I contemplate the one, the other does not exist for me. (Hägerström 1953, 267)

Hägerström's best-known work is to be found in the field of meta-ethics, however. Hägerström (1939; in English, 1964) presented a non-cognitivist theory in a 1911 lecture called "Om moraliska föreställningars sanning" ("On the truth of Moral Ideas"). His main meta-ethical thesis is usually understood to be a semantic thesis: Value sentences express the speaker's feelings, and so are neither true nor false. ${ }^{12}$ But he also held that there are no moral facts, and that we cannot have knowledge of right and wrong, good and bad in moral matters $(1939,51-2)$. That is to say, his theory does not only have a semantic, but also an ontological and an epistemological component.

\footnotetext{
${ }^{8}$ For more about Undén's analysis and its place in Scandinavian legal thinking, see Spaak (1994, 36-40).

9 Translated into English by Robert Carroll.

${ }^{10}$ Ross (1959, Preface) is explicit about his intellectual debt to Hägerström.

11 Paragraphs 2-6 in this section can be found, more or less verbatim, in Spaak (2002, 300-1).

12 On this point, see Hedenius (1963, 12-21). Danielsson (1993, 34-5) argues, however, that on Hägerström's analysis, the semantic thesis follows from a more fundamental, psychological thesis, according to which conceptions (or ideas) of value are neither true nor false.
} 
The main argument adduced by Hägerström in support of his non-cognitivist theory is usually said to be the following (ibid., 53-4). ${ }^{13}$ Since the act of evaluating something presupposes the existence of a feeling, and since the act of passing a judgment does not presuppose the existence of a feeling, an evaluation must be something different from a judgment. And since, on Hägerström's analysis, only judgments are true or false (because only judgments assert something about something), a value sentence, which is not a judgment, can be neither true nor false.

Having argued that value-sentences are neither true nor false, he concluded that moral philosophy cannot be a science in morality, but only a science about morality. Moral philosophy thus conceived, he explained, can only deal with the origin of moral evaluations, and should be based on psychological analysis and guided by a critical philosophical analysis of actual ideas (ibid., 63-5).

Interestingly, Hägerström (1953, 5-6) also advanced a theory of rights, which was not part of his non-cognitivist theory. ${ }^{14}$ Although non-cognitivist theory is meant to apply to value sentences in general, an exception must be made for sentences formulated in terms of rights. On Hägerström's analysis, rights sentences are necessarily false, since they involve the ascription of magical powers to the right-holder, which powers do not and cannot exist. ${ }^{15}$

If we consider Ross's analysis in light of Hägerström's naturalism, noncognitivism, and the analysis of the concept of a right, we can perhaps better understand Ross's naturalist, anti-metaphysical approach to the study of law and morals and the consequent preference for an analysis of the concept of a legal right as a connective concept. Let us now turn to consider more closely the advantages of Ross's analysis.

\section{The Idea of a Connective Concept}

First and most important, I believe that the concept of ownership does play the role in legal thinking suggested by Ross. I find it hard to believe that there is anything to the concept of ownership over and above the connection between operative facts and legal consequences, as Ross said, and even if there is, it does not seem to influence legal thinking.

Second, this type of analysis seems to be applicable more generally to a number of other legal (or moral) concepts, ${ }^{16}$ and this indicates that Ross has hit upon something that is of interest in legal (or moral) thinking more generally. Consider, for example, the concept of a judge. Does the term "judge" refer to anything over

\footnotetext{
${ }^{13}$ For an analysis and discussion of Hägerström's main argument, see Danielsson (1990) and Petersson (1990).

${ }^{14}$ For a brief discussion of Hägerström's theory of rights, see Danielsson (1989/90, 182-46).

${ }^{15}$ Enrico Pattaro has suggested in email correspondence that on Hägerström's analysis, rights statements are not authentic statements, which can be true or false, but rather pseudostatements, on the ground that the concept of a right is a self-contradictory idea. But, as I say, I believe that Hägerström's view was rather that rights statements are necessarily false, on the grounds that there are and can be no supernatural forces in the world of space and time. As for contradictions, including "self-contradictions," such as ( $\mathrm{P} \&-\mathrm{P})$, it is worth noting that logicians take them to be false, not meaningless. See, e.g., Suppes (1957, 36-41). I would like to thank Lennart Åqvist for discussing this question with me.

${ }^{16}$ This was clear to Ross himself. See Ross $(1957,821)$; see also Wedberg $(1951,262)$ and Eckhoff $(1969,76-7)$.
} 
and above the fact that certain operative facts, such as appointment by a competent organ, give rise to certain legal consequences, such as the legal power to try certain types of cases? I do not think so, and I believe the same can be said about the concept of a professor, the concept of a court, the concept of a legal person, the concept of citizenship, the concept of jurisdiction, the concept of marriage, the concept of territory, and other important legal concepts. ${ }^{17}$

Clearly, there are also legal (or moral) concepts that do not fit this type of analysis. Consider, for example, the concept of invalidity. Does the term "invalidity" refer to anything over and above the fact that certain operative facts, namely, the grounds of invalidity, give rise to certain consequences, such as judgment for invalidity, claim for compensation, and freedom to abide by or not to abide by a decision that is invalid? As a matter of fact, I think it does. As I see it, each ground of invalidity gives rise to one single legal consequence, namely, that it is no longer the case that one ought to act in accordance with the legal norm, decision, or contract in question. If I am right about this, we should not conceive of the consequences of the grounds of invalidity, such as claims for compensation, as legal consequences that should be comprised within the concept of invalidity. ${ }^{18}$

\section{The Concept of Ownership}

As we have seen, Ross and the other participants in the Scandinavian rights debate focused on one particular type of legal right concept, namely, the concept of ownership. But, one may ask, what about the concept of a right to performance of contract, the concept of a right to free speech, or the concept of a right to leave one's country? Indeed, Carl Wellman, having observed that Ross conceives of a legal right as "a linguistic abbreviation for a very complicated set of legal rules," objects to Ross's analysis that ownership is a status rather than a legal right:

This analysis seems to fit ownership, Ross' paradigm case, very well. I suspect, however, that ownership is not a typical legal right. It is much more like citizenship, a status that confers a variety of rights, than like such typical rights as the right to free speech, to due process, or to performance of contract. When one acquires the status of citizenship, one acquires a number of distinct rights, such as the right to vote, the right to police protection within the state, and the right to diplomatic protection abroad. Similarly, when one acquires ownership in something, one acquires the right to exclusive use of that thing, the right to dispose of that thing, and the right to lend it to another. Thus ownership would appear to be a legal status rather than a paradigm case of a legal right. (Wellman 1978, 217-8)

But even if ownership is, as Ross assumes, a legal right, the problem with his analysis is that the practical benefit of conceiving of other types of legal right concept, such as the ones mentioned above, is nowhere near as impressive as it is in the case of the concept of ownership. The problem is that in these cases rights statements do not render the content of a number of legal norms in a convenient

\footnotetext{
17 Lindahl $(2003,111-3)$ rightly points out that although we may in a wide sense call intermediate (or connective) concepts like the ones under consideration meaningless "vehicles of inference," not all intermediate concepts are on an equal footing with these concepts. Some intermediate concepts are, as Lindahl puts it, operative.

${ }_{18}$ For more on this topic, see Spaak $(1994,60-1)$.
} 
manner. For a person has a right to free speech or a right to leave his country by virtue of being a citizen, and he has the right to performance of contract by virtue of having entered into a contract; and this means that there is really only one operative fact at work in these other cases, namely, that of being a citizen or having entered into a contract.

One might perhaps object to my criticism that Ross's analysis was never intended to account for the concept of a legal right in general, but only for the concept of ownership and perhaps certain other concepts that have a similar structure. ${ }^{19}$ But that would be a mistake. For in the course of his analysis, Ross repeatedly speaks of the concept of a legal right, even though he keeps using the same example, viz. the concept of ownership (see, e.g., Ross 1959, chap. 6; 1957, 817-8, 824-5); and he clearly believes that his analysis is applicable to simple concepts like "claim" and "duty," too $(1957,817,821)$.

\section{The Functional Unity of Legal Rights ${ }^{20}$}

I said in Section 1 that Ross's attempt to distinguish the concept of a legal right from other concepts that might also be conceived of as connective concepts is not satisfactory, since it does not indicate what is necessary, but only what happens to be the case, and that it needs to be supplemented with an analysis along the lines of the choice (or interest) theory of rights. I shall now explain this in more detail.

Having observed that on Ross's analysis any of a number of operative facts implies each one of a set of legal consequences, Wellman $(1978,118)$ complains that "Ross seems never to have asked, and certainly does not answer, the question of why it is that this totality of legal consequences goes together in the law." Wellman's observation seems pertinent, but I shall argue that Ross's analysis can be supplemented so as to be able to account for (what Wellman calls) the functional unity of legal rights. On closer inspection, Ross's quite casual characterization (in Section 2 above) of the situations in which we typically say that a person has a legal right is actually reminiscent of the so-called choice (or will) theory of rights, according to which the right-holder has a legally respected choice.

The reason why Ross is content with these sketchy remarks is that he rejects an analysis along the lines of the choice theory, or the interest theory as misguided, on the grounds that both these theories are premised on the unrealistic assumption that legal rights have an essence that can be determined. There is, he explains (1959, 188), no point in debating whether rights are interest, will, or something else when we know that the term "legal right" does not correspond "to any reality arising between the conditioning facts and the conditioned consequence." I cannot, however, see that we have to assume that rights have an essence in order to be able to maintain with good sense, say, that $A$ has a legal right to do $F$ if, and only if, $A$ has a legally respected choice in regard to the doing of $F$. Let us take a quick look at the choice theory in order to see that this is so.

The choice theory can be traced back to the writings of Bernhard Windscheid $(1906,156)$, who held that the right-holder has some sort of power or dominion of volition over somebody else's will. Although the concept of "power of volition"

19 This objection was suggested to me by Lars Lindahl.

${ }^{20}$ Paragraphs 4-8 in this section can be found, more or less verbatim, in Spaak (1994, 144-50). 
may be impossible to explicate satisfactorily, the basic idea of Windscheid's analysis-that the will of the right-holder is of decisive importance-is sound and has been further developed by thinkers such as Hans Kelsen (1945, 75-90), H. L. A. Hart (1973, 197), Carl Wellman (1985), Nigel Simmonds (1998), and Hillel Steiner (1998). Let us focus on Hart's analysis.

Hart primarily examines rights of private law, distinguishing three main types of right: claim-rights, liberty-rights, and power-rights. These three have in common, he says, that the right-holder has a legally respected choice $(1973,197)$. That is to say, he stresses the agent's choice and emphasizes that, in the case of claim-rights, the important thing is that the legal system has given the agent the possibility to decide for himself whether or not the duty corresponding to the right must be fulfilled $(1953,49)$. Thus the right-holder, through his ability to choose, controls the duty of the obligated person, thereby becoming, Hart $(1973,192)$ says, "a smallscale sovereign."

The fullest measure of control comprises, Hart explains, three distinguishable elements: the power (i) to waive or extinguish the corresponding duty, (ii) to enforce the duty by, e.g., suing for compensation if the obligated person does not fulfill his obligation, and (iii) to waive or extinguish the obligation to pay compensation the obligated person must give if he does not fulfill his obligation (ibid.). This extensive control is mostly at hand in the context of private law, but Hart points out that we have good reasons to speak of rights outside of private law as well, not least in social law where persons who fulfill certain requirements are entitled to certain benefits. According to Hart, a restricted control over the duty corresponding to the right is thus sufficient.

Hart admits that the theory he has introduced is less suitable to characterize a fourth type of right, namely, immunity-rights, which exist chiefly in the bills of rights in various constitutions, because in these cases the right-holder does not have such control over the corresponding duty (ibid. 197-8). Moreover, critics of the choice theory of rights point out that we have good reasons to speak of rights also in contexts where the agent cannot be said to have a legally respected choice. For example, Neil MacCormick $(1977,197)$ points out that an individual has the right not to be grievously assaulted despite lacking the power to waive the other party's duty not to assault him. It would be strange, MacCormick says, if an individual were to have the right not to suffer certain types of minor physical harm (since the victim may waive the duty in question), but not the right not to suffer grievous bodily harm (since the victim may not waive this duty).

We see, then, that even though the choice theory of rights cannot account for all the things we normally refer to as legal rights, it does not, as Ross thought, involve unacceptable metaphysical assumptions. This means that Ross's analysis can be combined with an analysis along the lines of the choice theory (or, for that matter, the interest theory) to help distinguish the concept of a legal right from other concepts that might also be conceived of as connective concepts. In this way, Ross can offer a decent account of the functional unity of legal rights.

\section{The Concept of a Legal Right in Statutory Language}

One might, however, object that Ross's analysis cannot account for the concept of a legal right as it occurs in the formulation of statutory provisions, and that 
therefore the area of application of Ross's analysis is more restricted than one might believe at first. For example, Article 25, paragraph 1 of the Swedish Contracts Act provides that the buyer may cancel the contract if the seller does not deliver the goods on time, provided that the delay is important to the buyer and that the seller realized or should have realized this. This is commonly understood to mean that when the conditions for cancellation are met, the buyer has the right to cancel the contract. And here the concept of a legal right does not connect a disjunction of operative facts and a conjunction of legal consequences. Instead, the term "legal right" seems here to refer to the legal consequence that the buyer may cancel the contract (compare Ekelöf's analysis in Section 3).

But if we move from the level of the legal object language to the level of the legal meta language, that is, to the level of statements about the law, we find that the statement "the buyer has the right to cancel this contract" can be conceived of as connecting a disjunction of operative facts, such as the existence of damaged goods or delay in the delivery of the goods, and the legal consequence that the buyer may cancel the contract. I therefore conclude that whereas the counter-example concerns the concept of a legal right as it occurs in the legal object language, Ross's analysis should be taken to apply solely to the concept of a legal right as it occurs in the legal meta language. ${ }^{21}$ We might say, in keeping with this, that Ross's analysis concerns the concept of a legal right when used to handle the content of the law, not when used to express or state it. ${ }^{22}$ If this is right, the objection under consideration misses its target, though it does make it clear that the area of application of Ross's is quite restricted. Of course, the objection to Ross's analysis discussed in Section 6-that the practical benefit of conceiving of other types of legal right concepts than the concept of ownership is not anywhere near as impressive as it is in the case of the concept of ownership-still applies. For the practical benefits of using the concept of a legal right in this case are not very impressive.

\section{A Problem of Circularity}

The Norwegian legal theorist Torstein Eckhoff has objected to Ross's analysis that it gives rise to a problem of infinite regress. He begins by explaining that Ross's analysis assumes that a statement such as " $p$ owns $X$ " can be an acceptable translation of a number of other statements such as "If $p$ has purchased $X, p$ is free to make use of $X$ pretty much as he pleases," or "If $p$ has inherited $X, p$ can and may sell X.," etc. (Eckhoff 1969, 63-4) He then maintains that it is impossible to spell out these other statements, except in terms of the concept of a legal right or related concepts: If we formulate the sentences in question in a more precise and complete manner, the concept of a legal right or its cognates have a tendency to reappear (ibid., 67-8). For example, the (truncated) sentence "If purchase, then

\footnotetext{
${ }^{21}$ Ross has more than once pointed out that it is the task of legal scholars to systematize the content of law using the "technique of presentation" proposed by him. See, e.g., Ross (1959, 171-2; 1957, 821). Similarly, it is clear from the examples he gives-such as " $p$ has a right of ownership in regard to $X^{\prime \prime}$ - that he has in mind discourse on the meta-level, that is, discourse about the law.

${ }^{22}$ For an account of the distinction between handling and stating the content of the law, see Frändberg $(1987,84)$.
} 
vindication" may be spelled out as follows: If $A$ has purchased an object from $H$, who was the owner of the object at the time, if $A$ has not ceased being the owner of the object, and if the object is now in $B^{\prime}$ s possession and $B$ does not have the right to use the object, then $A$ can vindicate the object from $B$ (ibid., 67). Eckhoff therefore concludes that Ross's analysis suffers from a problem of infinite regress or, as I prefer to say, a problem of circularity, in the sense that the analyst will be analyzing the concept of a legal right partly in terms of the concept of a legal right (ibid., $67-8) .{ }^{23}$

Eckhoff points out that Anders Wedberg's attempt to solve this problem, which utilizes the idea of a recursive procedure, is not satisfactory (ibid., 68-71). ${ }^{24} \mathrm{He}$ notes that the proposed solution involves the assumption that there is something we may call first-hand ownership-where $p$ 's ownership of $X$ cannot be traced back to another people's ownership of $X$-and the claim that there are chains of ownership tracing any given person's ownership of $X$ back to the situation of first-hand ownership. But, Eckhoff objects, in law there simply is no first-hand ownership in the sense contemplated by Wedberg, because it is impossible to characterize first-hand ownership, except in terms of ownership (ibid., 69-70).

Nevertheless, Eckhoff does not argue that Ross's analysis should be rejected. In Eckhoff's opinion, Ross's analysis illuminates important features of legal usage and legal thinking. And even though the analysis turns out be problematic in certain respects, he believes that our efforts to solve these problems may well yield new insights (ibid., 75).

I agree with Eckhoff that it does seem difficult to translate the original statement into other statements without making use of the concept of a legal right or related concepts at some point; and, as I see it, this means that we face a problem of circularity (or, if you will, infinite regress) in the sense explained. But I take a less sanguine view of the problem than Eckhoff does: One simply cannot define the concept of a legal right in terms of the concept of a legal right. Hence the problem must be solved. Let us now turn to consider a possible solution to this problem.

\section{Syntax, not Semantics}

I have been assuming that Ross's analysis was an attempt to define the concept of a legal right, that it was intended to account for the linguistic meaning of the term "legal right" (I think of the concept of $X$ as the meaning, specifically, the sense, of the term X), and Eckhoff $(1969,63-5)$ clearly made the same assumption. But what if Ross was not concerned with the meaning of the term "legal right"? What if he really meant it when he said that the term "legal right" lacks "independent

${ }^{23}$ Eckhoff believes that we may be able to avoid the infinite regress problematic by conceiving of legal rules as rules addressed to the judge as follows: If $p$ has purchased $X$, if $p$ claims that he is entitled to vindicate $X$ from $q$, and if $p$ can produce evidence that supports his claim, then the judge must determine that $q$ must hand over $X$ to $p$. But Eckhoff also points out that the meanings of the rules thus translated (roughly "If purchase, then ownership" and "If ownership, then vindication") and the above-mentioned complex rule addressed to the judge are not sufficiently similar for this to be an acceptable analysis. For, he says, it does not seem reasonable to think of the content of rules of civil procedure as part of the content of a rule like "If purchase, the ownership" (ibid., 71-5).

${ }^{24}$ See Wedberg $(1951,267-70)$. 
semantic reference" when it occurs in legal argumentation, that "[a]ny attempt to take it as a designation of either legal facts or legal consequences, of both together, or of anything else whatever, is foredoomed to failure" (Ross 1957, 822-3) ${ }^{25}$ If, then, he was not concerned with the meaning, but with the function of the concept of a legal right in legal thinking, one might argue that the objections discussed in Sections 8 and 9 miss their target, since they seem to concern precisely the meaning of the term "legal right."

I believe the distinction between the meaning and the function of the term "legal right" is relevant to the circularity objection (in Section 9), but not to the statutory language objection (in Section 8). The reason why it is relevant to the circularity objection is that the analysis of the meaning of the term "legal right," but not the analysis of the function of the concept of a legal right, will be undermined if this term reappears on a more basic level of discourse, viz. in the statements that assert a connection between operative facts and legal consequences. The reason why the distinction is not relevant to the statutory language objection is that this objection can easily be rephrased in accordance with the move from the semantic to the syntactic level of discourse. For the critic might argue that when used in the formulation of certain statutory provisions, the concept of a legal right just does not connect a disjunction of operative facts and a conjunction of legal consequences, as Ross's analysis suggests, and that this is so whether we speak of the meaning or of the function of the concept of a legal right. At any rate, we can avoid the statutory language objection by restricting the area of application of Ross's analysis to the legal meta-language.

The connective analysis cannot explain the meaning of the term "legal right," if this term reappears on a more basic level of discourse, because one explains the meaning of one term, $t$, with the help of other terms whose meanings are not only (reasonably) clear, but also independent of the meaning of $t$. If, for example, one aims to explain the meaning of "bachelor" with the help of "unmarried" and "man," then the meanings of these latter terms may not in turn depend on the meaning of "bachelor"-if they do, one clearly has not advanced the issue at all.

The connective analysis may well, however, explain the connective function of the concept of a legal right, even though this concept may reappear on a more basic level of discourse. For, as far as I can see, the connective function of the concept of a legal right on one level of discourse is independent of any connective function this concept might have on a more basic level of discourse. For example, if I explain the connective function of the concept of a legal right in the statement "François Hollande owns the mansion on the hill" by pointing out that the concept of ownership connects a number of statements about operative facts (such as "Hollande has purchased this mansion," or "Hollande has inherited this mansion") and a number of statements about legal consequences (such as "Hollande can sell the mansion," or "Hollande may use the mansion as he pleases"), and that in this

${ }^{25}$ I owe this objection to Sven Danielsson. Note, however, that Lindahl (2004, 189-90) has made the same point. Per Olof Ekelöf (1952) appears to have interpreted Ross's writings in the same way. For more on the utility of meaningless expressions, see Wedberg (1951, 272-3). 
way the statement in question renders the content of a number of legal norms in a convenient manner, then this analysis will not in any way be undermined if it turns out that we cannot understand, say, the statement "Hollande can sell the mansion," unless we presuppose the concept of ownership.

The relevant difference between these two cases-the case of meaning and the case of function-seems to be that the former, but not the latter, case involves understanding a certain thought-content. To understand the meaning of, say, "bachelor" or "legal right" is clearly different from grasping a syntactic connection between statements about operative facts and statements about legal consequences.

\section{The Connective Model of Conceptual Analysis}

It is worth noting that one might be able to avoid the circularity problematic, even if one sticks to the view that Ross's analysis concerns the meaning of the term "legal right," by giving up the attempt to find terms whose meanings are independent of the meaning of "legal right," and advocating instead a connective model of conceptual analysis of the type proposed by P. F. Strawson (1992, chap. 2). On Strawson's analysis, one analyzes, or rather elucidates, the concept under consideration, not by breaking it down into its simple elements, but by grasping its connections with other concepts. One is to imagine, Strawson explains, "the model of an elaborate network, a system, of connected items, concepts, such that the function of each item, each concept, could, from the philosophical point of view, be properly understood only by grasping its connections with others, its place in the systemperhaps better still, the picture of a set of interlocking systems of such a kind" (ibid., 19).

Strawson prefers the connective model of conceptual analysis to the usual model (which he calls the reductive model), precisely because he believes the reductive model tends to give rise to problems of circularity, whereas the connective model does not. He reasons that the philosopher who is analyzing a concept "reductive style" is likely to find, sooner or later, that the concept he is analyzing, $C$, will turn up among the concepts in terms of which he is analyzing $C$. He adds that the worry about circular analysis on the part of so many philosophers is precisely what shows that they really adhere to the reductive model-if they did not, they would not be worried about problems of circularity (ibid., 19-20).

Although I find Strawson's analysis intuitively appealing, I have doubts about the distinction between the idea of assembling a concept by a kind of logical or conceptual construction out of simple or simpler concepts, as the reductive model requires us to do, and the idea of grasping the connections between the concept in question and other concepts, as the connective model requires us to do. The problem, as I see it, is simply that the difference between assembling a concept in the way indicated and grasping the connections between that concept and other concepts is not clear, and this means that it will be difficult to determine whether a given analysis of a concept should be thought to conform to the reductive rather than the connective model, or vice versa.

Consider the concept of knowledge in this regard. Assuming that knowledge can be analyzed as justified true belief, should we say that this analysis conforms to the reductive model, in the sense that we conceive of the concept of knowledge as being composed of the concepts "justified," "true," and "belief"? Or should we say 
instead that it conforms to the connective model, in the sense that we conceive of the concept of knowledge as being connected with these other concepts? And what, exactly, is the difference?

It is obvious that a closer investigation of this difficult problematic falls outside the scope of this article. What is important in this context is that if Strawson is right, Eckhoff's objection to Ross's analysis would be unsuccessful after all, even if this analysis, properly understood, did concern the meaning of the term "legal right."

\title{
12. Concluding Remarks
}

We see, then, that while the objection to Ross's analysis considered in Section 8 (the statutory language objection) can be met by restricting the area of application of the analysis to the legal meta language, and that the objection considered in Section 9 (the circularity objection) can be met by opting for a syntactic interpretation of Ross's analysis, or, perhaps, by shifting to a connective model of conceptual analysis, the objections considered in Sections 6-7 (the ownership objection and the functional unity objection), which cannot be easily met, are not very serious. Thus given the advantages of Ross's analysis-the absence of troublesome metaphysical commitments, its obvious applicability to a number of legal concepts, including the concept of a legal right, the practical benefits in the case of the concept of ownership, and its elegance-we may conclude that Ross's analysis deserves our continued attention.

\author{
Department of Law \\ Stockholm University \\ Stockholm \\ Sweden
}

E-mail: Torben.Spaak@juridicum.su.se

\section{References}

Bealer, G. 1987. The Philosophical Limits of Scientific Essentialism. Philosophical Perspective-Metaphysics 1: 289-365.

Coleman, J. 2001. The Practice of Principle. Oxford: Oxford University Press.

Danielsson, S. 1989/90. Värdenihilismen i praktiken. Forskningsprofiler/Uppsala universitet: Installationsföreläsningar: 13-9.

Danielsson, S. 1990. Hägerströms huvudargument. Filosofisk tidskrift 11: 16-22.

Danielsson, S. 1993. Några värdenihilismer. In Huvudinnehåll. Tolv filosofiska uppsatser. Ed. Å. E. Andersson and N.-E. Sahlin, 33-46. Nora: Nya Doxa.

Eckhoff, T. 1969. Litt om det juridiske rettighetsspråk. In Festskrift till Alf Ross. Ed. M. Blegvad, 63-78. Copenhagen: Juristforbundets.

Ekelöf, P. O. 1945. Juridisk slutledning och terminology. Tidsskrift for rettsvitenskap: 211-70.

Ekelöf, P. O. 1952. Är termen rättighet ett syntaktiskt hjälpmedel utan mening? In Skrifter tillägnade Vilhelm Lundstedt, 546-59. Stockholm: Svensk juristtidning.

Frändberg, Å. 1987. An Essay on the Systematics of Legal Concepts. Scandinavian Studies in Law 31: 81-115. 
Hägerström, A. 1939. Om moraliska föreställningars sanning. In A. Hägerström, Socialfilosofiska uppsatser. Ed. Martin Fries, 35-65. Stockholm: Bonniers.

Hägerström, A. 1953. Inquiries into the Nature of Law and Morals. Ed. K. Olivecrona. Uppsala: Kungliga humanistiska vetenskapssamfundet i Uppsala.

Hägerström, A. 1964. On the Truth of Moral Propositions. In A. Hägerström, Philosophy and Religion. Trans. R. T. Sandin, 77-96. New York: Humanities.

Hart, H. L. A. 1953. Definition and Theory in Jurisprudence. The Law Quarterly Review 70: 37-60.

Hart, H. L. A. 1973. Bentham on Legal Rights. In Oxford Essays in Jurisprudence (2nd Series). Ed. A.W.B. Simpson, 171-201. Oxford: Oxford University Press.

Hedenius, I. 1963, Om rätt och moral. Stockholm: Wahlström \& Widstrand.

Kelsen, H. 1945. General Theory of Law and State. Cambridge, Mass.: Harvard University Press.

Leiter, B. 2002. Naturalism in Legal Philosophy. In The Stanford Internet Encyclopedia of Philosophy (Fall 2002 Edition). Ed. E. N. Zalta, 1-16. Available at http:// plato.stanford.edu/archives/fall2002/entries/lawphil-naturalism/.

Lindahl, L. 2003. Operative and Justificatory Grounds in Legal Argumentation. In Logic, Law, Morality. Thirteen Essays in Practical Philosophy in Honour of Lennart Åqvist. Eds. K. Segerberg and R. Sliwinski, 111-26. Uppsala: Uppsala University, Department of Philosophy.

Lindahl, L. 2004. Deduction and Justification in the Law. The Role of Legal Terms and Concepts. Ratio Juris 17: 182-202.

Lundstedt, A. V. 1928. Har Duguits rättsteori något underlag i fakta? In Festskrift tillägnad Axel Hägerström. Eds. Filosofiska föreningen i Uppsala and Juridiska föreningen i Uppsala, 84-110. Uppsala and Stockholm: Almqvist \& Wiksell.

MacCormick, N. 1977. Rights in Legislation. In Law, Morality and Society. Essays in Honour of H. L. A. Hart. Eds. P. M. S. Hacker and J. Raz, 189-209. Oxford: Oxford University Press.

Olivecrona, K. 1962. Legal Language and Reality. In Essays in Honour of Roscoe Pound. Ed. R. A. Newman, 151-91. Indianapolis: The American Society for Legal History.

Petersson, B. 1990. Tolkningen av Hägerströms huvudargument. Filosofisk tidskrift 11: 16-24.

Raz, J. 1985. Authority and Justification. Philosophy and Public Affairs 14: 3-29.

Ross, A. 1957. Tü-tü. Harvard Law Review 70: 812-25.

Ross, A. 1959. On Law and Justice. Berkeley: University of California Press.

Simmonds, N. E. 1998. Rights at the Cutting Edge. In A Debate Over Rights. Eds M. H. Kramer, N. E. Simmonds, and H. Steiner, 113-232. Oxford: Oxford University Press.

Spaak, T. 1994. The Concept of Legal Competence. Aldershot: Dartmouth.

Spaak, T. 2002. (Review of) Legal Theory, ed. P. Wahlgren. Archiv für Rechts- und Sozialphilosophie 88: 298-304.

Steiner, H. 1998. Working Rights. In A Debate over Rights. Eds M. H. Kramer, N. E. Simmonds, and H. Steiner, 233-301. Oxford: Oxford University Press.

Strahl, I. 1947. Till frågan om rättighetsbegreppet. Tidsskrift for rettsvitenskap (1946): 204-10; (1947), pp. 481-514.

Strawson, P. F. 1992. Analysis and Metaphysics. An Introduction to Philosophy. Oxford: Oxford University Press.

Sundby, N. K. 1968. Legal Right in Scandinavian Analyses. Natural Law Forum 13: 72-107.

Suppes, P. 1957. Introduction to Logic. New Jersey: van Nostrand. 
JOBNAME: No Job Name PAGE: 17 SESS: 14 OUTPUT: Mon Oct 20 16:36:40 2014 SUM: 3ABF9AB2 /Xpp84/wiley_journal_R-S/RAJU/raju_v27_i4/raju_12054

Undén, Ö. 1928. Några synpunkter på begreppsbildning inom juridiken. In Festskrift tillägnad Axel Hägerström. Eds. Filosofiska föreningen i Uppsala \& Juridiska föreningen i Uppsala, 167-77. Uppsala and Stockholm: Almqvist \& Wiksell.

Waluchow, W. J. 1994. Inclusive Legal Positivism. Oxford: Clarendon.

Wedberg, A. 1951. Some Problems in the Logical Analysis of Legal Science. Theoria 17: 246-75.

Wellman, C. 1978. Legal Rights. In Uppsalaskolan—och efteråt. Ed. S. Strömholm, 213-21. Stockholm: Almqvist \& Wiksell.

Wellman, C. 1985. A Theory of Rights. Totowa: Rowman \& Allanheld.

Windscheid, B. 1906. Lehrbuch des Pandektenrechts.Vol. 1. Ed. Th. Kipp. Frankfurt on Main: Literarische Anstalt Rütten \& Loening. 


\section{Please correct and return this set}

Please use the proof correction marks shown below for all alterations and corrections. If you wish to return your proof by fax you should ensure that all amendments are written clearly in dark ink and are made well within the page margins.

\begin{tabular}{|c|c|c|}
\hline Instruction to printer & Textual mark & Marginal mark \\
\hline Leave unchanged & ... under matter to remain & ( ) \\
\hline $\begin{array}{l}\text { Insert in text the matter } \\
\text { indicated in the margin }\end{array}$ & $h$ & $\begin{array}{l}\text { New matter followed by } \\
h \text { or } h \otimes\end{array}$ \\
\hline Delete & $\begin{array}{l}\text { I through single character, rule or underline } \\
\text { or }\end{array}$ & $\sigma$ or $\sigma(x)$ \\
\hline $\begin{array}{l}\text { Substitute character or } \\
\text { substitute part of one or } \\
\text { more word(s) }\end{array}$ & I through letter or & $\begin{array}{l}\text { new character / or } \\
\text { new characters / }\end{array}$ \\
\hline Change to italics & — under matter to be changed & $\leftarrow$ \\
\hline Change to capitals & $\equiv$ under matter to be changed & $\equiv$ \\
\hline Change to small capitals & $=$ under matter to be changed & $=$ \\
\hline Change to bold type & $\sim$ under matter to be changed & $\sim$ \\
\hline Change to bold italic & $\bar{\sim}$ under matter to be changed & $\tilde{\omega}$ \\
\hline Change to lower case & Encircle matter to be changed & $\Rightarrow$ \\
\hline Change italic to upright type & (As above) & \\
\hline Change bold to non-bold type & (As above) & \\
\hline Insert 'superior' character & $\begin{array}{l}/ \text { through character or } \\
K \text { where required }\end{array}$ & $\begin{array}{l}y^{\prime} \text { or } y \\
\text { under character } \\
\text { e.g. } y^{2} \text { or } y^{2}\end{array}$ \\
\hline Insert 'inferior' character & (As above) & $\begin{array}{l}\lambda \\
\text { over character } \\
\text { e.g. } \hat{\Sigma}\end{array}$ \\
\hline Insert full stop & (As above) & $\odot$ \\
\hline Insert comma & (As above) & , \\
\hline Insert single quotation marks & (As above) & $\begin{array}{l}\dot{y} \text { or } \dot{x} \text { and/or } \\
\dot{y} \text { or } \dot{y}\end{array}$ \\
\hline Insert double quotation marks & (As above) & $\begin{array}{l}\ddot{y} \text { or } \ddot{x} \text { and/or } \\
\ddot{y} \text { or } \ddot{x}\end{array}$ \\
\hline Insert hyphen & (As above) & 1 \\
\hline Start new paragraph & 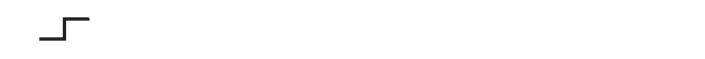 & 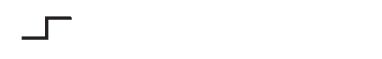 \\
\hline No new paragraph & $\infty$ & $\omega$ \\
\hline Transpose & $\sqcup$ & $\sqcup$ \\
\hline Close up & linking $\bigcirc$ characters & \\
\hline $\begin{array}{l}\text { Insert or substitute space } \\
\text { between characters or words }\end{array}$ & $\begin{array}{l}\text { I through character or } \\
K \text { where required }\end{array}$ & \\
\hline $\begin{array}{l}\text { Reduce space between } \\
\text { characters or words }\end{array}$ & $\begin{array}{l}\text { between characters or } \\
\text { words affected }\end{array}$ & $\uparrow$ \\
\hline
\end{tabular}

